\title{
KRAKOWSCY ALUMNI NA WYDZIALE TEOLOGICZNYM UNIWERSYTETU WARSZAWSKIEGO I W SEMINARIUM GEÓWNYM (1818-1833)
}

„Jak religia i ojczyzna wspólna jest obydwom niepodległym krajom, tak wspólna i nierozdzielna troskliwość biskupa zajmuje, aby dla obu państw diecezję jego składających, światłych i przykładnych dostarczał kapłanów" - pisał 29 IX 1819 r. bp Jan Paweł Woronicz do Senatu Rzeczypospolitej Krakowskiej, gdy odpowiadając na wezwanie owego rządu, obiecywał wysyłanie części kleryków na Wydział Teologiczny zarówno miejscowego, jak warszawskiego Uniwersytetu ${ }^{1}$.

Okrągło zdeklarowane intencje biskupa-poety odpowiadały wprawdzie zamiarom, lecz równoczesne podwyższanie intelektualnego i moralnego poziomu duchowieństwa miało się okazać trudniejsze niż zazwyczaj. Dostęp do dwu wyższych uczeni i to przy urzędowych naciskach na dostarczenie im słuchaczy, nie stał się przecież przełomem w stanie wykształcenia kleru diecezji krakowskiej. Większa część jej obszaru, 239 na 285 parafii, położona była w Królestwie Polskim, a diecezja podlegała kościelnej polityce warszawskiej Komisji Rządowej Wyznań Religijnych i Oświecenia Publicznego (KRWRiOP).

Uniwęrsytet Warszawski erygował 19 VII 1816 r. car Aleksander I a teologiczny fakultet $\mathrm{w}$ stolicy Królestwa zatwierdził papież Pius VII dnia 3 X 1818 r. Program i skład personalny Wydziału wyznaczała KRWRiOP, a nie miejscowy ordynariusz, jak tego wymagało erekcyjne breve. Abp Franciszek Malczewski dochodząc swych prerogatyw żądał, by mógł opiniować kandydatów na wykładowców i aprobować programy, gdyż w przeciwnym razie nie można by „za złe poczytać biskupom nieufności, która by wstrzymywała ich od posyłania do takiej szkoły młodzi duchownej swych diecezji". KRWRiOP obiecała więc komunikować prymasowi program wykładów teologicznych, przyznała mu prawo

1 Archiwum UJ, S I 306. 
obecności na egzaminach i uznała jako oczywistość podleganie księży profesorów odpowiednim władzom kościelnym ${ }^{2}$. Był to raczej sukces formalny metropolity niż kompromis, gdyż faktyczny wpływ na kierunek nauczania utrzymywała nadal Komisja Wyznań. Ministerstwo to utworzone 17 X 1816 r., uzyskało 18 III 1817 r. cesarskie „Postanowienie o stopniu dozoru i opieki rządu nad duchowieństwem rzymsko-katolickim i funduszami przez nich posiadanymi". Postanowienie było tajne, oddawało Kościół poid ścisły nadzór władz państwowych, stanowiło sukces prezesa KRWRiOP, Stanisława Kostki Potockiego, a przegraną kleru, któremu marzyła się staropolska niezależność czy niemal udzielność Kościoła ${ }^{3}$. Tymczasem stanowisko Aleksandra I skazywało episkopat Królestwa na wspólpracę z Komisją Wyznań, a opór przeciw ścisłemu uzależnieniu od niej księży nie ujawniał się wyraźnie aż do czasu dymisji Potockiego w 1820 r., po której w 1821 r. zreorganizowano KRWRiOP wprowadzając do niej prymasa i dwu biskupów ${ }^{4}$.

O stylu polityki kościelnej władz Królestwa Polskiego, zwłaszcza w pierwșzym pięcioleciu, decydował w dużej mierze oddziedziczony po Księstwie Warszawskim pogląd na stosunek państwa do Kościoła. Wprowadzone wraz z Kodeksem Napoleona małżeństwa cywilne, niewielkie wypłaty rządowe $\mathrm{w}$ miejsce zabranych majątków kościelnych, spory o poziom kształcenia duchowieństwa - nadal animowały kler Królestwa, mimo że zabrakło już nieprzejednanego arcybiskupa gnieźnieńskiego Ignacego Raczyńskiego. $\mathrm{Na}$ początku XIX w. dążność do podporządkowania Kościoła państwu mogła pochodzić z dwu źródeł - ze starej józefińskiej tendencji usiłującej przekształcić kler w narzędzie absolutnej monarchii, albo też z tradycji racjonalizmu oświeceniowego, żywotnego jeszcze w systemie napoleońskim, a zmierzającego do ograniczenia wpływu Kościoła na masy. Potocki kierując pracami KRWRiOP reprezentował nie tyle ową orientację programowo antykościelną, ile tę pierwszą - rząd winien regulować stosunki wyznaniowe dla dobra samego Kościoła, by ten mógł stawać się coraz lepszym instrumentem oddziaływania na masy ${ }^{5}$.

Orientacja taka nie była odosobniona. Zarówno w czasach Księstwa Warszawskiego, jak i Królestwa Polskiego narzekano na mizerne wy-

2 J. Bieliński, Królewski Uniwersytet Warszawski (1816-1831), t. 2, Warszawa $1911,6,12,20 \mathrm{n}$.

3 E. Kipa, Materiały do dziejów organizacji Kościoła katolickiego $w$ Królestwie Polskim. 1815-1820. Dymisja Stanisława Potockiego, ,Teki Archiwalne”, 3 (1954) 166-169; S. Kieniewicz, rec. tegoż, „Przegląd Historyczny”, 46 (1955) 631 n.

4 E. Kipa, jw., 169, 177; ,Dziennik Praw Królestwa Polskiego", 7 (1821) 174.

5 M. Loret, Stosunek Kościoła do państwa w Księstwie Warszawskim, „Przegląd Narodowy", 7 (1914) t. 13, 130-134; tenże, Watykan a Polska (1815-1832), „Biblioteka Warszawska”, 73 (1913) t. 290, 210-212; S. Kieniewicz, jw.; tenże, Historia Polski 1795-1918, Warszawa 1969, 44. 
kształcenie duchowieństwa. „Zaprzeczyć nie można - pisał anonimowy publicysta krakowski w 1816 r. - iż znaczna część plebanów, wikarych i zakonników jest tak ograniczonego pojęcia, iż się równa częstokroć samym nawet wieśniaksom". Domagano się, by księża odczytywali gotowe kazania, skoro nie potrafią ich dobrze mówić. Wskazywano, że obniżona pozycja społeczna księdza, związana z duchem epoki i ze spadkiem dochodów kleru, powoduje unikanie kariery kościelnej przez arystokratyczną czy utalentowaną młodzież - ,zostają zatem tacy, którzy poczuwając się do swej nieudolności - - pewni, iż żaden stan nie byłby zyskowniejszym dla nich, czynią ofiare jak najemnik znaglony do pracy niedostatkiem życia. Jakichże uczniów duchownych spodziewać się można z tych osób? Jakiego światła?". Prezes krakowskiego Senatu, Wodzicki, pisał w 1821 r. do Marcina Badeniego, ministra sprawiedliwości w Warszawie: „Deptała Europa duchownych przez lat 30 i lada kto do tego stanu się tylko garnie.- Abyśmy nie zostali bez księży, lada kogo święcono" ${ }^{6}$.

Wielkopańskiej wyższości wobec plebejuszy garnących się do kapłaństwa, towarzyszyła krytyczna, a nie odosobniona ocena stanu edukacji alumnów KRWRiOP podnosiła ,zaniedbanie nauk w seminariach - i dziś we wszystkich stronach kraju dająca się widzieć niezdatność duchownych do sprawowania posługi parafialnej". Na sejmie Królestwa Polskiego w 1820 r. odezwał się głos posła powiatu krakowskiego na temat umysłowej i moralnej formacji duchowieństwa: „Wychodzący bowiem młodzi księża $\mathrm{z}$ seminarium po większej części wysłuchawszy tylko dawne nauki, ale nie objąwszy onych, są prawie tak ciemni, jak gdy weszli". Udawszy się na parafie złym przykładem życia ,wiejski lud w ciemności barbarzyńskiej zachowują i wszystkie klasy sceptyków w niedowiarstwie utwierdzają" ". Zupełnie podobnie przemawiał do swoich kleryków na Stradomiu bp Woronicz, również w 1820 r., tłumacząc im na rekolekcjach, że należy się kształcić, by potrafić ,,wyjaśniać prawdy odwieczne prostaczkom i wyżej myślącym", gdyż niewiedza wystawi ich „na pośmiech, a religię na większe wyszydzenie”. Ich bowiem „rzemiosłem jest, aby nie tylko umieć chwytać tych prostaczków, te rybki, które same lezą w sieć Chrystusową, ale i one wielkie i harde ryby, co

${ }^{6}$ S. Cynar, Ignacy Raczyński, ostatni prymas Polski porozbiorowej $i$ jego działalność duszpasterska w okresie Księstwa Warszawskiego, Londyn 1954, 54 n.; Rozprawa o przyczynach ciemnoty niektórych osób duchownych stanu niższego $i$ o ciemnocie ludu wiejskiego, Kraków 1816, 4, 9; R. Zurkowa, Krakowskie miscelanea kulturalno-obyczajowe z listów Stanisława Wodzickiego (1818-1824), „Rocznik Biblioteki PAN w Krakowie", 7/8 (1961/62) 219; por. W. Kwiatkowski, Sprawa pruskiej reorganizacji seminariów duchownych $w$ Warszawie 1798-1802, Warszawa 1936, 40, 135 n., 168-170.

7 E. Kipa, jw., 215; [D. Oebschelwitz], Uwagi nad stanem polityczno-moralnym rzeczy publicznych $w$ Królestwie Polskim przedstawione izbie poselskiej na sejmie walnym w roku 1820 przez ... [b.m.r.], 20, 24; por. S. Cynar, jw., 53, 56. 
gwałtem z niej wydrzeć się pragną". Jednocześnie biskup, jak wielu współczesnych, nisko oceniał zarówno słabe przygotowanie naukowe samych Misjonarzy, jak i ich metody dydalktyczne oraz niewolnicze trzymanie się kazuistyki, gdy przymawiał im: ,Z tych definicyjków waćpanowie nie będziecie mądrymi, nikogo tym nie nawrócicie" ${ }^{8}$.

Fakt, że nauczanie seminaryjne uznane zostało za anachroniczne i mało w praktyce przydatne, zarówno przez ordynariusza, jak i w ministerium Potockiego, nie przesądzał jeszcze o ich harmonijnej współpracy na polu poprawiania edukacji duchowieństwa. Różnice wynikały nie tylko z rozbieżnych ocen merytorycznych np. ortodoksyjności proponowanych podręczników, lecz także z wzajemnych uprzedzeń ${ }^{9}$. „W każdej akcji rządu kler skłonny był dopatrywać się antyreligijnego podkładu i niedowiarstwa. Z drugiej strony do zbytku wojowano straszakiem klerykalnym" ${ }^{10}$. Wspomniane już kontrowersje kościelno-rządowe wokół początków teologii w Uniwersytecie Warszawskim są również przykładem owego ograniczonego zaufania wzajemnego.

Trudne były początki owego fakultetu w mieście pozbawionym tradycji wyższych studiów teologicznych, przy braku profesorów i pomieszczeń. Prowadzący seminarium Św. Krzyża Misjonarze zgłosili dwu kandydatów na wykładowców, księży Rzymskiego i Szymonowicza, a sturentom udostępnili część budynku. Wkrótce jednals wycofali się z prowadzenia zajęć, rozpoczęli kampanię przeciw Wydziałowi, przesadzając w zarzutach na temat nieprawowiernej formacji intelektualnej i podejrzanego trybu życia swoich lokatorów, których jednak nie chcieli wyrzucać ze względu na biskupów. Ci' zaś wysyłając obowiązkowo swych alumnów, czynili to czasem bez przekonania, nie dobierając specjalnie kandydatów. Wskutek tego „młodzież duchowna wstępująca do Wydziału Teologicznego była na ogół grubiańska, prostacka, niesforna i pod względem obyczajowym wiele bardzo do życzenia pozostawiająca" ${ }^{11}$.

Bp Woronicz przynaglany przez KRWRiOP skierował w 1818 r. do Warszawy swoich pierwszych aspirantów na słuchaczy teologii. Wybór padł na dwóch kleryków, Wojciecha Kaweckiego i Wincentego Balickiego, którzy z pięknymi wynikami ukończyli II i III kurs w seminarium na Stradomiu. Starano się więc wysłać uzdolnionych kadydatów.

8 J. Kracik, Sprawa reformy studiów $w$ krakowskim seminarium duchownym za rządów biskupa Woronicza (1815-1828), „Roczniki Teologiczno-Kanoniczne”, 20 (1973) $41-44$.

9 Tamże, $41-44,47-50$.

10 M. Loret, Watykan a Polska, 213.

11 Z. Skiełczyński, Archidiecezja warszawska w latach 1818-1830, w: Studia z historii Kościoła w Polsce, t. 4, pod red. E. H. Wyczarwskiego, Warszawa 1978, 135 n.; J. Bieliński, jw., 74; M. Godlewski, Epizod z dziejów Seminarium Głównego $w$ Warszawie w 1831 roku, ,Collectanea Theologica”, 21 (1949) 16 n. 
Dopiero z czasem miało 'się okazać, że obaj zawiedli pokładane w nich nadzieje. Mieszkając wraz z kolegami w konwikcie u Św. Krzyża byli świadkami nienajlepszego współżycia gospodarzy i lokatorów. Ci ostatni umieli przekonać swoich biskupów i uzyskać od nich zgodę na prywatne zamieszkanie. Jako pierwszy pozwolił na to - mając własne, nie najlepsze wspomnienia z świętokrzyskiego seminarium - bp Woronicz. Jego alumn Kawecki znalazł $\mathrm{w}$ mieście stancję, ale też po pewnym czasie zamienił sutannę na wojskowy mundur. Ponieważ nie był to przypadek odosobniony, a młodzi teologowie rozproszeni po prywatnych kwaterach tracili powołanie, biskupi znowu polecali im mieszkać $u$ 'Misjonarzy ${ }^{12}$.

Po rocznym pobycie w stolicy Królestwa Balicki pisał 23 IX 1819 r. list do krakowskiego konsystorza, gdzie dziękował za zaufanie, lecz prosił o umożliwienie oczekiwania święceń w seminarium stradomskim. Motywował to niskim stypendium studenckim. Wprawdzie otrzymywal pomoc materialną i z konsystorza, ale nie śmiałby jej nadużywać $w$ przyszłości. Nie mając zaś znikąd pomocy musiałby wcześniej czy później opuścić uczelnię. Druga racja była innej natury: „Abym wyznał, co czuję, powiem otwarcie, że niektóre nowe opinie akademiczne nie zgadzają się ze starymi i ciągle przez lat trzy słuchanymi naukami. Jeżeli prześwietny Konsystorz tego wymagać będzie - jaśniej się wytłumaczę. Do tego obciążają nas naukami cywilnymi, które trudność wzmagają”. Prosi, by „Konsystorz dozwolił wrócić mu w spokojne zacisze seminarium, abym tam oczekiwał, dopóki w nauki lepiej usposobiony i laty dojrzały" będzie mógł otrzymać święcenia. Biskup i Konsystorz odrzucili prośbę (,,dla uniknięcia odpowiedzialności przed Rządem krajowym"), tłumacząc się brakiem kompetencji wobec słuchaczy Uniwersytetu, obiecali petentowi i jego koledze dalszą pomoc, a przemilczawszy zastrzeżenia co do teologicznego nowatorstwa, polecili niezwłocznie udać się do Warszawy. Był to albo wyraz lojalnego oportunizmu, albo też nie wzięto zbyt serio stawianych zarzutów, gdyż ich tłem mogło być nie tylko poczucie zagrożonej ortodoksji, lecz i zwykła niechęć do nauki, bijąca $\mathrm{z}$ nadesłanego pisma. Zresztą podanie datowane było $\mathrm{z}$ krakowskiego seminarium, gdzie nagle otwarly się oczy studenta, co adresatom mogło nasuwać myśli o wpływie dawnych wychowawców, znanych z niechęci do uniwersyteckich studiów kleryków, na powstanie nadesłanego elaboratu. Balicki pozostał jednak na Stradomiu uczęszczając wraz z kil-

12 Archiwum Księży Misjonarzy w Krakowie na Stradomiu (AMS), H I 4 , Lista alumnów z ocenami; S. Chodyński, Seminaria duchowne w Polsce, w: Encyklopedia kościelna, pod red. M. Nowodworskiego, t. 25, 82 n.; A. Jougan, Ks. prymas Woronicz. Monografia, cz.' 1, Lwów 1908, 23 n.; Z. Skiełczyński, jw., 136. 
ku kolegami na krakowski Wydział Teologiczny ${ }^{13}$ - Z czasem miał zostać znanym kaznodzieją ${ }^{14}$.

Diecezja, krakowska miała dostarczać warszawskiemu Wydziałowi Teologicznemu trzech stypendystów, w tym jednego zakonnika ${ }^{15}$. Był nim w latach 1818-1821 należący do bożogrobców Antoni Hieronim Walniewicz ${ }^{16}$. Jego miejsce zajął w 1822 r. nauczyciel szkół wojewódzkich w Kielcach, były nowicjusz skasowanego klaştoru cystersów w Jędrzejowie i kandydat do seminarium, Karol Beythel ${ }^{17}$. Studentem diecezjalnym był od 1820 do 1823 r. kielecki kleryk Maciej Majerczak, przyszły administrator diecezji kielecko-krakowskiej ${ }^{18}$, a od 1821 r. Tomasz Szczepanowski ${ }^{19}$, który wraz z Feliksem Kirkorem z Krakowa i Piorem Żebrowskim z Kielc był stypendystą warszawskim jeszcze w $1824 r^{20}$

Dwaj ostatni nie zdążyli już skorzystać z warszawskiej wszechnicy, gdyż KRWRiOP 22 III 1823 r. zawiesiła wykłady teologii na Wydziale, a młodzież rozesłano do diecezji macierzystych. Bezpośrednim powodem tego posunięcia było znieważenie jednego z wychowawców misjonarskich przez studenta mieszkającego u Sw. Krzyża. Sprawa została wyolbrzymiona i intrygancko wykorzystana przez komisarza pełnomocnego przy Radzie Stanu, Mikołaja Nowosilcowa, który już od r. 1820 tropił rzekome spiski studenckie i wprowadzał system policji szkolnej.

13 Archiwum Kurii Metropolitalnej w Krakowie (AKM), Acta Consistorii 1819, nr 1543; Arch. UJ, S I 64, s. 134; J. Kracik, art. cyt., 41-47.

14 Wincenty Balicki (1798-1844). Pochodzil z Brzeska, został proboszczem w Lisiej Górze k. Tarnowa. Ogłosił w r. 1831 pracę o Tarnowie, wydał w 1835 r. we Lwowie 2 tomy kazań. W wyniku zatargu $\mathrm{z}$ władzą duchowna rzucił sutannę zostając w 1839 r. predykantem ewangelickim w Prusach; w r. 1841 wydał w Królewcu 2-tomową Postyllę luterańską. - R. Gerber, Studenci Uniwersytetu Warszawskiego 1808-1831. Stownik biograficzny, Wrocław 1977, 457.

15 AKM, Akta seminarium 1801-1833, Woronicz do KRWRiOP, 21 IX 1822.

16 Od 1822 r. profesor liceum św. Barbary w Krakowie, od 1841 prepozyt u św. Mikołaja. - Elenchus venerabilis cleri dioecesis Cracoviensis, Cracoviae 1841-1859; R. Gerber, jw., 473.

17 Zob. przyp. 15.

18 Maciej Majerczak (1800-1870), ur. w Starej Wsi na Spiszu. Po święceniach w r. 1823 zostal profesorem Pisma św. i dogmatyki w seminarium kieleckim, następnie proboszem w Stopnicy 1832-66, regensem seminarium w Kielcach 184148, oficjałem 1847; od 1848 był administratorem diecezji krakowskiej w Królestwie Polskim, w 1862 otrzymał sakrę biskupią; zmarł jako wikariusz apostolski i administrator diecezji kielecko-krakowskiej. - D. Olszewski, Biskup Maciej Majerczak, reformator życia religijnego $w$ diecezji kielecko-krakowskiej, w: Chrześcijanie, t. 5, pod red. B. Bejze, Warszawa 1980, 9-39; R. Gerber, jw., 465 n.

${ }_{19}$ Tomasz Szczepanowski (1802-1865), szlachcic, syn nadleśniczego z obwodu samborskiego. Nie notowany wśród alumnów seminariów krakowskiego i kieleckiego. Prawodopodobnie skierowany przez bpa Woronicza bezpośrednio do Warszawy. Współpracował w r. 1825 z o. Leśniewskim TJ przy reformie studiów cysterskich w Mogile; został sekretarzem Konsystorza krakowskiego, a od $1832 \mathrm{r}$. proboszczem w Mogile. - R. Gerber, jw., 470; Elenchus [...] 1832-1866; S. Załęski, Jezuici $w$ Polsce, t. 5, cz. 2, Kraków 1909, 622 n.

20 AKM, Akta seminarium 1801-1833; KRWRiOP do bpa Woronicza, 26 IV 1823, 6 V 1824; R. Gerber, jw., 474. 
Utrąciwszy Wydział senator Cesarstwa dążył do izolowania kleryków od świeckich kolegów, a starania episkopatu o zakład zamknięty, podległy władzy kościelnej, spotkały się $\mathrm{w}$ tej sytuacji z aprobatą Petersburga. Tak doszło do utworzenia Seminarium Głównego, otwartego przez abpa Wojciecha Skarszewskiego w popaulińskim klasztorze 22 IX 1825 r. Związek zakładu z Wydziałem był luźny - profesorowie zostawszy bez słuchaczy chodzili wykładać do Seminarium, alumnów nie wciągano do spisu studentów, chociaż promocje magisterskie czy doktorskie odbywały się w Uniwersytecie. Mianowanie wykładowców i zatwierdzanie programu zależało od prymasa, jako prezesa Sekcji Duchownej w KRWRiOP. Koszta utrzymania 40 kleryków, bo tylu przewidziano z całego Królestwa, ponosił rząd. Poziom naukowy nie był wysóki, chociaż lepszy niż w przeciętnym seminarium. Alumni Seminarium Głównego nie wykazywali na ogół wielkiej pasji studiowania, kolejni rektorzy, księża Źółtowski i Onoszko, nie odznaczali się talentami pedagogicznymi, zaś opinia publiczna doby Powstania Listopadowego zarzucała uprawiane$\mathrm{mu}$ w zakładzie systemowi wychowania trzymanie podopiecznych. w izolacji, obskurantyzm i tłumienie uczuć narodowych. Seminarium Główne przetrwało carską likwidację Uniwersytetu. w 1831 r., ale już oczywiście bez możliwości uzyskiwania stopni naukowych ${ }^{21}$.

W r. 1829 Konsystorz polecił rektorowi ze Stradomia wytypować dwu odpowiednich kandydatów do Seminarium Głównego. Wybrano alumnów po drugim kursie, Edwarda Saskiego i Jana Waligórskiego. Obaj 22-letni młodzi ludzie nie zobaczyli jednak Warszawy, skierowali bowiem do władz diecezjalnych deklarację tej treści: - Dziękują za zaufanie, ale nie mają książek, ubrań, są ubodzy, a krewni daleko, by prosić ich o sfinansowanie podróży. Jest późno, rozpoczynają się już zajęcia. Dlatego „w żaden sposób do Warszawy jechać nie możemy, obydwa nie życzymy sobie w Warszawie zostawać, przeczuwając jakieś dla nas tylko nieszczęście”. Tu się podjęli pracy, tu chcą dokończyć swego powołania i służyć Bogu. Proszą o litość. Pismo powędrowało ad acta, a do stolicy pojechali dwaj klerycy z Kielc — świeżo przyjęty Leon Zajączkowski i Wojciech Kalatowicz po I roku seminarium ${ }^{22}$.

Jeśliby nawet obaj niedoszli słuchacze Seminarium Głównego z Krakowa byli samodzielnymi autorami przedstawionej przez siebie argumentacji, zastanawiający byłby fakt, że przełożeni ich właśnie zapropo-

${ }_{21}$ M. Godlewski, jw., 18-26; Z. Skiełczyński, jw., 136-138; R. Żmuda, Dziatalność dydaktyczna i pisarska profesorów $i$ wychowawców Warszawskiej Akademii Duchownej 1837-1867, w: Studia $z$ historii Kościoła $w$ Polsce, t. 6, pod red. H. E. Wyczawskiego, Warszawa 1979, $27 \mathrm{n}$.

22 AKM, Akta seminarium 1801-1833, rektor seminarium ks. K. Brzozowski do Konsystorza, 30 IX 1829; Saski i Waligórski do Konsystorza, bez daty; Elenchus [… 1830, $117 \mathrm{n}$. 
- nowali na studia. Trudno bowiem przypuścić, by rektor pisząc ich nazwiska nie wiedział, jak bardzo wyjardu nie pragną. Wobec tego przypuszczenie o zbojkotowaniu zamiaru biskupa przez Misjonarzy wydaje się uzasadnione. Był to zresztą wyraz tej samej nieufności do studiów akademickich, jaką władze Zgromadzenia okazywały od lat wzbraniając się także przed kształceniem uniwersyteckim własnych adeptów, przygotowując przyszłych wykładowców seminaryjnych jedynie u Sw. Krzy$\dot{z ̇ a}$, gdzie nauczający prowadzili po killka, mie zawsze tych samych przedmiotów. W przeciwieństwie do innych zalkonów nie wysyłali Misjonarze swych kleryków ani na krakowski, ani na warszawski Wydział. Teologiczny czy do całkowicie zależnego od biskupów Seminarium Głównego. Pobożność przeciwstawiana wiedzy, a to w powoływaniu się na wolę założyciela, nie znalazła jednak uznania u metropolity Antoniego Fijałkowskiego, który w 1857 r. zagroził Misjonarzom w Królestwie za dalsze opieranie się przed gruntowniejszą edukacją, odebraniem tych seminariów, które jeszcze prowadzą ${ }^{23}$. Wszystko to pomaga zrozumieć, jaki był wpływ Zgromadzenia na dobór młodzieży duchownej studiującej teologię $\mathrm{w}$ Warszawie $\mathrm{i}$ to bez względu na to, czy kierowano ją tam z Krakowa czy Włocławka ${ }^{24}$.

Nadszedł koniec listopada 1830 r. i trudno było myśleć o spokojnym pobycie w Seminarium Głównym. Sekcja Duchowna KRWRiOP zawiesiła w nim zajęcia na czas nieokreślony. Obaj alumni diecezji krakowskiej, Kalatowicz i Zajączkowski, powrócili do swego seminarium w Kielcach, przywożąc ładne zaświadczenia o studiach i postępowaniu. Otrzymali subdiakonat i udali'się na parafie. Chcąc tam więcej pomóc i utrzymać się łatwiej, prosili o święcenia diakonatu, jakie niebawem przyjęli ${ }^{25}$. Ich rówieśnicy $w$ Krakowie $u$ franciszkanów, kapucynów i augustianów, a także kleryk ze Stradomia, udawali się w tym czasie na północ, by walczyć w Powstaniu ${ }^{28}$.

Zajęcia w Seminarium Głównym rozpoczęły się w marcu 1832 r.

23 J. Kracik, jw., 37-39, 53.

24 ,Misjonarze pamiętni przygód od akademików doznanych, gdy ci u Sw. Krzyża mieszkali, zawsze Akademii niechętni byli i najczęśsiej wysyłali mniej zdolnych i mniej żądnych nauki, którzy dlatego do końca wytrwac tam nie potrafili. Zazwyczaj więc opuszczali Akademię, gdy im doszły lata do święceń". KRWRiOP upominała biskupów w 1826 i 1835 r., by wysyłali alumnów chętnych do nauki i o stałym usposobieniu, a przerywający studia będą zmuszani do zwrotu kosztów. - S. Chodyński, Seminarium włocławskie. Szkic historyczny, Włocławek $1904,125 \mathrm{n}$.

25 AKM, Akta seminarium 1801-1833, rektor Seminarium Głównego ks. Jan Onoszko do bpa Skórkowskiego, $20 \mathrm{I} 1831$; Kalatowicz i Zajączkowski do Konsystorza, 11 VI 1831; AMS, H I 5, Wykazy wyświęconych.

26 Spośród 34 kleryków kieleckich 11 udało się do wojska. - J. Kracik, Duchowieństwo Wolnego Miasta Krakowa $i$ Galicji wobec Powstania Listopadowego, „Roczniki Humanistyczne”, 28 (1980) z. 2, 163; T. Wróbel, Dzieje seminarium duchownego $w$ Kielcach na przestrzeni 250 lat, w: Księga jubileuszowa 1727-1977, Poznań 1977, 98. 
Z diecezji krakowskiej wysłano nowych alumnów. Byli to kieleccy klerycy Wincenty Hantulski i Konstanty Rodkiewicz. Na wakacje obaj przywieźli o sobie dobre opinie, ale pierwszy nie powrócił już do Warszawy - spotykamy go w r. 1833/34 wśród alumnów III kursu w seminarium kieleckim ${ }^{27}$. Zakład ten dostarczył $w$ następnych latach jeszcze kilku słuchaczy Seminarium Głównego, a następnie Akademii Duchownej Rzymsko-Katolickiej, jaką w Warszawie, w miejsce Seminarium Głównego, utworzył 16 X 1835 r. car Mikołaj I. Jednak nie biskup krakowski kierował tam alumnów. Od r. 1833 jego władza w części diecezji położonej w Królestwie Polskim, w odwet za czynne poparcie Powstania Listopadowego przez bpa Karola Skórkowskiego, została przez rząd rosyjski zawieszona ${ }^{28}$.

\section{LES SEMINARISTES CRACOVIENS À LA FACULTE DE THÉOLOGIE DE L'UNIVERSITÉ DE VARSOVIE, PUIS AU SEMINAIRE PRINCIPAL ENTRE 1818 ET 1833}

Rés u mé

Ouverte en 1818 la Faculté de Théologie de 1'Université de Varsovie forma les séminaristes de tous les diocèses du Royaume de Pologne choisis par les évêques. Cracovie en envoya $2-3$ chaque année. Le niveau de la Faculté se ressentit de l'absence de traditions théologiques à Varsovie, de la pénurie de professeurs et de locaux, ainsi que du manque de confiance des évéques à l'égard du programme des études contrôlé par les autorités civiles. D'autres tensions existaient également dues à l'ingérence du gouvernement cherchant à mettre l'Eglise en tutelle pour faire d'elle un instrument apte à agir les masses. La Congrégation de la Mission qui avait en mains la direction d'une partie des séminaires diocésains, mal disposée à l'égard des études universitaires de Varsovie comme de Cracovie, avait elle aussi son mot à dire dans le choix des candidats envoyés dans la capitale du Royaume et qui s'avérèrent souvent peu avides de science. Une partie des séminaristes abandonna, d'autres interrompirent les êtudes. En 18201821 Alexandre I $^{\mathrm{r}}$ changeant la politique confesionnelle, tenta d'imposer à l'Eglise un certain modèle de restauration et de rôle de gardien de l'ordre établi. Cela condûisit en 1823 à la suspension de l'activité de la Faculté et en 1825 à la fondation du Séminaire Principal complètement soumis à l'épiscopat.

27 AKM, Akta seminarium 1801-1833, Sekcja Duchowna KRWRiOP do Konsystorza, 15 III 1832; ks. Onoszko do bpa Skórkowskiego, 10 VIII 1832; Elenchus [...] 1834,124 .

28 A. Pleszczyński, Dzieje Akademii Duchownej Rzymsko-Katolickiej Warszawskiej, Warszawa 1907, 18; M. Żywczyński, Geneza i następstwa encykliki „Cum primum" z 9 VI 1832 r., Warszawa 1935, 218. O nieuwzględnionym w badanych źródłach Sylwestrze Grzybowskim, który jako alumn kielecki studiował w Seminarium Głównym 1825-29, został mgrem teologii i był później kanonikiem krakowskim - zob. R. Gerber, jw., 462.

32 - Analecta Cracoviensia 